\title{
Bonding rearrangement in amorphous silicon nitrides deposited by hot-wire chemical vapor deposition upon thermal annealing
}

\author{
Y. Mai, V. Verlaan, C.H.M. van der Werf, Z.S. Houweling, R. Bakker, J.K. Rath, \\ R.E.I. Schropp* \\ Utrecht University, Faculty of Science, Department of Physics and Astronomy, SID - Physics of Devices, P.O. Box 80 000, 3508 TA Utrecht, \\ The Netherlands
}

Available online 5 February 2008

\begin{abstract}
The bonding rearrangement upon thermal annealing of amorphous silicon nitride $(\mathrm{a}-\mathrm{SiN} \times \mathrm{H})$ films deposited by hot-wire chemical vapor deposition was studied. A wide range of $\mathrm{N} / \mathrm{Si}$ atom ratio between 0.5 and 1.6 was obtained for the a-SiN $: \mathrm{H}$ sample series by varying the source gases ratio only. Evolutions of $\mathrm{Si}-\mathrm{N}, \mathrm{Si}-\mathrm{H}$ and $\mathrm{N}-\mathrm{H}$ bonds upon annealing were found to depend strongly on the $\mathrm{N} / \mathrm{Si}$ atom ratio of the films. According to the above observations, we propose possible reaction pathways for bonding rearrangement in $\mathrm{a}-\mathrm{SiN}_{x}: \mathrm{H}$ with different $\mathrm{N} / \mathrm{Si}$ ratios.
\end{abstract}

(C) 2008 Published by Elsevier B.V.

PACS: 68.60.-p; 68.55.Jk; 78.30.-j; 78.55.Qr

Keywords: Silicon; Solar cells; Photovoltaics; Chemical vapor deposition; Rutherford backscattering; FT-IR measurements

\section{Introduction}

Amorphous silicon nitride $\left(\mathrm{a}-\mathrm{SiN}_{x}: \mathrm{H}\right)$ has been widely used in crystalline silicon (c-Si) solar cells for anti-reflection and surface passivation coatings [1,2]. In addition, $\mathrm{a}-\mathrm{SiN}_{x}: \mathrm{H}$ provides bulk passivation to the grain boundaries of multi-crystalline silicon (mc-Si) solar cells by atomic hydrogen in-diffusion, which is driven by a high-temperature annealing step, for example a 'firing' step $[3,4]$. Many studies on hydrogen passivation suggest that both the surface and bulk passivation capacity depends critically on the atom densities and bonding structure (such as $\mathrm{H}$ content, $\mathrm{Si}-\mathrm{N}$ bond density, mass density and/or $\mathrm{N} / \mathrm{Si}$ ratio) of the deposited a-SiN $x: \mathrm{H}$ film [3-7]. To discern the determinative factor of surface and bulk passivation, a systematic study on the bonding rearrangement and $\mathrm{H}$ out-diffusion in $\mathrm{a}-\mathrm{SiN}_{x}: \mathrm{H}$ upon thermal annealing is necessary.

\footnotetext{
${ }^{*}$ Corresponding author.

E-mail address: r.e.i.schropp@uu.nl (R.E.I. Schropp).
}

Many researchers have studied the effect of thermal annealing on plasma-deposited a-SiN ${ }_{x}: \mathrm{H}[3,8-10]$. However, a systematic experiment was seldom carried out for $\mathrm{a}-\mathrm{SiN}_{x}: \mathrm{H}$ deposited by hot-wire chemical vapor deposition (HWCVD). This is of interest because passivation of mc-Si solar cells by HWCVD a-SiN $\mathrm{S}_{x}: \mathrm{H}$ has been shown to be as effective as other methods of deposition, while much higher deposition rates can be obtained [7]. In this paper, we report a thermal annealing experiment of a series of a-SiN $x: \mathrm{H}$ with $\mathrm{N} / \mathrm{Si}$ atom ratio in the wide range from 0.5 to 1.6 . It was found that the evolution of $\mathrm{Si}-\mathrm{N}, \mathrm{Si}-\mathrm{H}$ and $\mathrm{N}-\mathrm{H}$ bonds depends critically on the N/Si ratio of the sample.

\section{Experimental}

Eleven a-SiN $x: \mathrm{H}$ films were deposited by HWCVD on $\mathrm{c}-\mathrm{Si}$ wafers at a substrate temperature of $450^{\circ} \mathrm{C}$. A description of the deposition system can be found elsewhere [11]. The source gases, $\mathrm{SiH}_{4}$ and $\mathrm{NH}_{3}$, were catalytically decomposed at four resistively heated tantalum filaments held at $2100^{\circ} \mathrm{C}$, leading to a high deposition rate of about $3 \mathrm{~nm} / \mathrm{s}$. 
The $\mathrm{NH}_{3}$ flow was the same for all depositions, while the $\mathrm{SiH}_{4}$ flow was varied to obtain different N/Si ratios ranging from 0.5 to 1.6 in the resulting films. The deposition time of each film was deliberately changed to keep the film thickness at about $300 \mathrm{~nm}$. The composition of the deposited samples was determined with elastic recoil detection (ERD) [12] using $50 \mathrm{MeV} \mathrm{Cu}^{8+}$ ions. Rutherford back scattering (RBS) experiment [13] with $2 \mathrm{MeV} \mathrm{He}^{+}$-atoms was used to accurately determine the mass density. The samples were annealed in a tube oven in a nitrogen atmosphere for different periods of time. The annealing temperature was kept at $800{ }^{\circ} \mathrm{C}$ since temperatures around this value are frequently used in the 'firing' step for mc-Si solar cell fabrication. The absorption peak intensity and bond configurations of $\mathrm{Si}-\mathrm{N}, \mathrm{Si}-\mathrm{H}$ and $\mathrm{N}-\mathrm{H}$ bonds were evaluated from Fourier transformed infrared (FT-IR) absorption spectra, measured before and after each step of annealing. Corrections for coherent and incoherent reflections were taken care of $[14,15]$ and intensive dry $\mathrm{N}_{2}$ purging was used during the FT-IR measurement to minimize the ambient $\mathrm{H}_{2} \mathrm{O}$ and $\mathrm{CO}_{2}$ signals.

\section{Results}

Under our deposition conditions, film properties, such as hydrogen content $\left(C_{\mathrm{H}}\right)$, mass density, surface and bulk passivation quality, were found to depend strongly on the $\mathrm{N} / \mathrm{Si}$ ratio $[7,16]$. The mass density increased, starting from $2.2 \mathrm{~g} / \mathrm{cm}^{3}$ at $\mathrm{N} / \mathrm{Si}$ of 0.5 , with increasing $\mathrm{N} / \mathrm{Si}$ ratio to a maximum of $3 \mathrm{~g} / \mathrm{cm}^{3}$ at $\mathrm{N} / \mathrm{Si}$ of $\sim 1.3$. From there on it decreased again, down to $2.2 \mathrm{~g} / \mathrm{cm}^{3}$ as N/Si increased up to $\sim 1.5$. Compared to the mass density, $C_{\mathrm{H}}$ has just an opposite trend and reached its minimum of $\sim 9$ at. $\%$ at $\mathrm{N} / \mathrm{Si} \approx 1.3$.

It was found that the evolutions of $\mathrm{Si}-\mathrm{H}$ and $\mathrm{N}-\mathrm{H}$ bonds in $\mathrm{a}-\mathrm{SiN}_{x}: \mathrm{H}$ behave in three different ways upon the thermal annealing, depending on the N/Si ratio. Fig. 1 shows the $\mathrm{Si}-$ $\mathrm{H}$ and $\mathrm{N}-\mathrm{H}$ peak intensities of such three typical samples as a function of annealing time. These peak intensities are normalized to the initial values before annealing. (i) In the Sirich samples with $\mathrm{N} / \mathrm{Si} \leqslant 1.02$, both $\mathrm{Si}-\mathrm{H}$ and $\mathrm{N}-\mathrm{H}$ peak intensity decreased with the increasing annealing time (see Fig. 1(a) for example). (ii) In the samples close to stoichiometry with $\mathrm{N} / \mathrm{Si} \approx 1.3$, the $\mathrm{N}-\mathrm{H}$ peak intensities still decreased with increasing annealing time. However, annealing increased the $\mathrm{Si}-\mathrm{H}$ peak intensities in the first $4 \mathrm{~min}$ and then reduced them slowly afterwards (Fig. 1(b)). (iii) The Nrich samples with $\mathrm{N} / \mathrm{Si}$ of $\sim 1.5$ initially had an as-deposited $\mathrm{Si}-\mathrm{H}$ stretching peak at $\sim 2210 \mathrm{~cm}^{-1}$. Annealing reduced this $\mathrm{Si}-\mathrm{H}$ peak within $4 \mathrm{~min}$. Further annealing, however, introduced a new peak at $\sim 2175 \mathrm{~cm}^{-1}$. After 16 min of annealing, the new absorption peak increased up to 5 times stronger than the initial peak at $\sim 2210 \mathrm{~cm}^{-1}$ and remained almost constant till 60 min (see Fig. 1(c)). It can be seen in Fig. 1 that $\mathrm{Si}-\mathrm{H}$ and $\mathrm{N}-\mathrm{H}$ of all types of samples nearly reached saturation after $16 \mathrm{~min}$ of annealing at $800^{\circ} \mathrm{C}$.

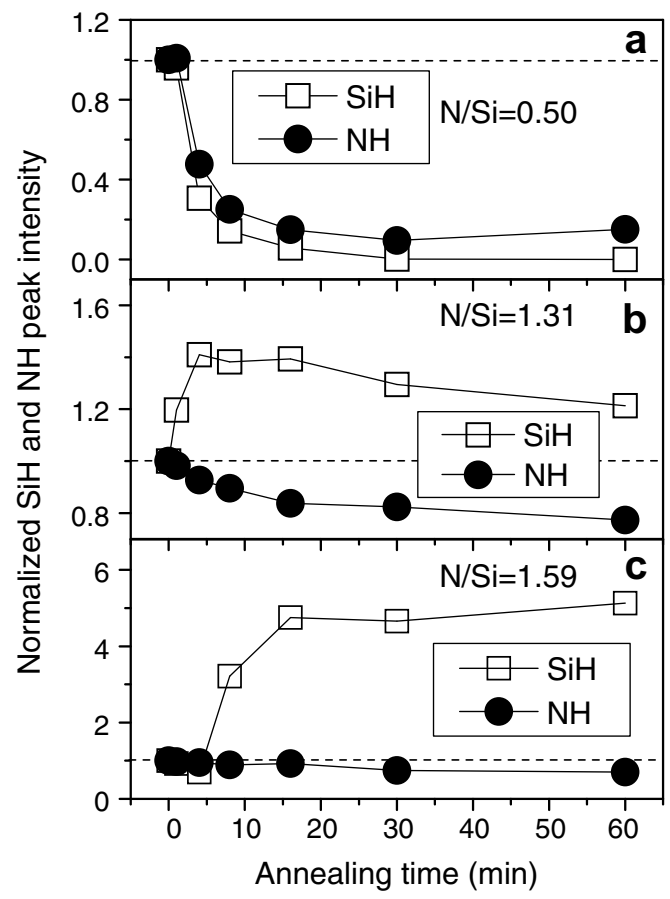

Fig. 1. Normalized $\mathrm{Si}-\mathrm{H}$ and $\mathrm{N}-\mathrm{H}$ peak intensities of three typical a-SiN ${ }_{x}: \mathrm{H}$ samples with different $\mathrm{N} / \mathrm{Si}$ ratio.

Therefore, we will mainly show the film properties after 16 min of annealing in the following.

The intensity ratios of $\mathrm{Si}-\mathrm{H}$ and $\mathrm{N}-\mathrm{H}$ peaks after thermal annealing relative to the initial peak intensities were found to be N/Si dependent. As can be seen in Fig. 2, more
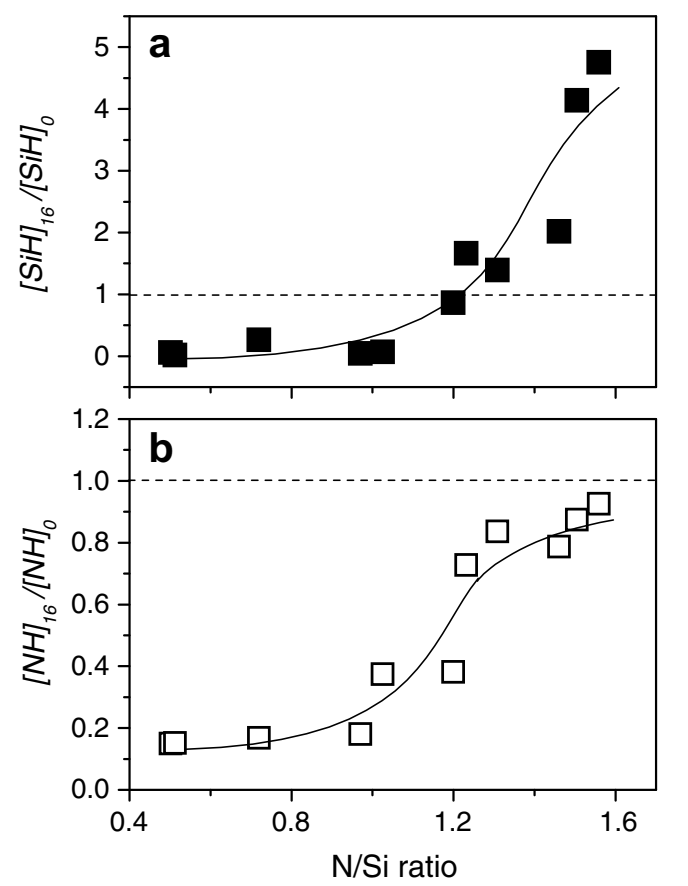

Fig. 2. Ratios of $\mathrm{Si}-\mathrm{H}$ (a) and $\mathrm{N}-\mathrm{H}$ peak intensities (b) after 16 min of annealing at $800^{\circ} \mathrm{C}$ relative to the initial peak intensities. The data are plotted as a function of $\mathrm{N} / \mathrm{Si}$ ratio. 
$\mathrm{N}$-rich samples maintained relatively more bonded $\mathrm{H}$ content in the film after $16 \mathrm{~min}$ of annealing.

Fig. 3 shows the $\mathrm{Si}-\mathrm{H}$ peak positions of the eleven samples before annealing and after $16 \mathrm{~min}$ of annealing at $800{ }^{\circ} \mathrm{C}$. The initial $\mathrm{Si}-\mathrm{H}$ peak position increased almost linearly from $\sim 2140$ to $\sim 2220 \mathrm{~cm}^{-1}$ as N/Si ratio increased from 0.50 to 1.59 . Thermal annealing decreased the width of the $\mathrm{Si}-\mathrm{H}$ peaks and shifted the peak positions to a higher wavenumber in the Si-rich samples with $\mathrm{N} / \mathrm{Si}<1.02$. The newly developed $\mathrm{Si}-\mathrm{H}$ in the $\mathrm{N}$-rich samples $(\mathrm{N} / \mathrm{Si}$ of $\sim 1.5$ ) showed a maximum intensity at $\sim 2175 \mathrm{~cm}^{-1}$, which is about $35 \mathrm{~cm}^{-1}$ smaller than the initial peak position. Thermal annealing hardly changed the $\mathrm{Si}-\mathrm{H}$ peak position of samples with $\mathrm{N} / \mathrm{Si}$ of $\sim 1.3$. A direct observation in this figure is that $\mathrm{Si}-\mathrm{H}$ peaks converge to a small range between 2170 and $2200 \mathrm{~cm}^{-1}$ after annealing.

A peak shift of the $\mathrm{Si}-\mathrm{N}$ peak to higher wavenumber was observed in almost all samples after annealing, indicating a change in the $\mathrm{Si}-\mathrm{N}$ bonding configuration. Fig. 4 shows the difference between the $\mathrm{Si}-\mathrm{N}$ peak intensity before and after $16 \mathrm{~min}$ of annealing. The contribution of

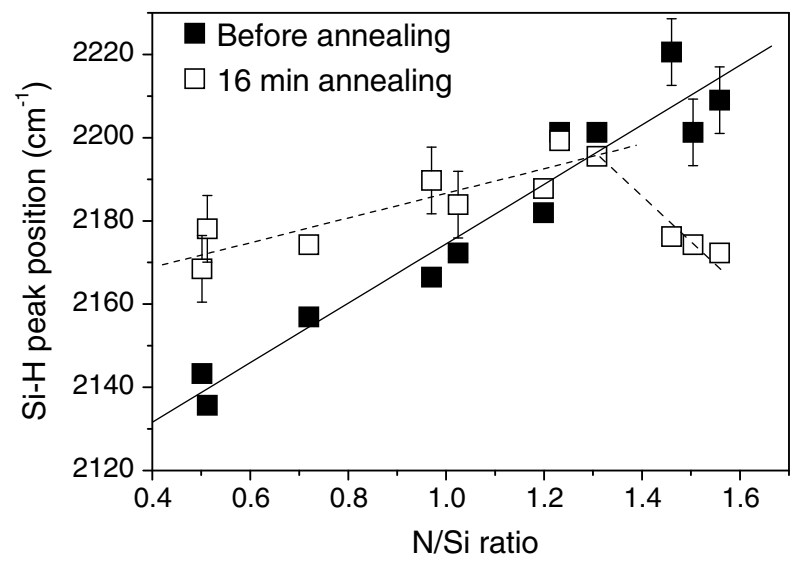

Fig. 3. Peak positions of the $\mathrm{Si}-\mathrm{H}$ absorption peak before annealing (solid squares) and after $16 \mathrm{~min}$ (open squares) of thermal annealing at $800^{\circ} \mathrm{C}$.

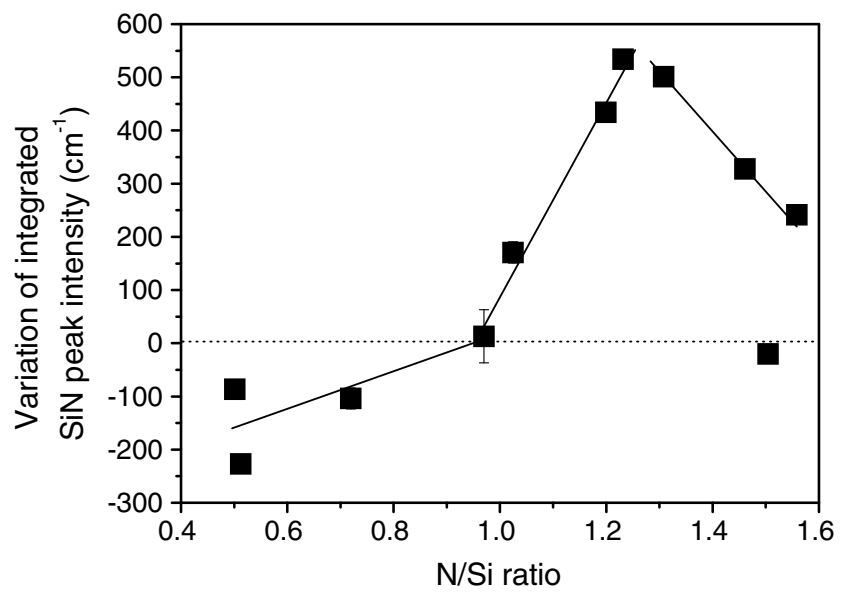

Fig. 4. Sixteen minutes of thermal annealing changed the integrated $\mathrm{Si}-\mathrm{N}$ peak intensity of the a-SiN ${ }_{x}: \mathrm{H}$ films with different $\mathrm{N} / \mathrm{Si}$ ratios.

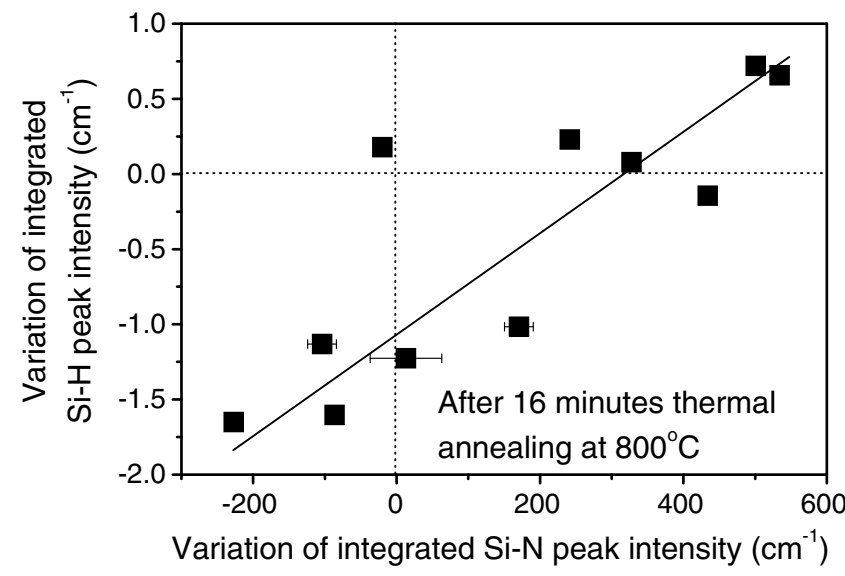

Fig. 5. The absolute variation of $\mathrm{Si}-\mathrm{H}$ peak intensities after $16 \mathrm{~min}$ of annealing at $800^{\circ} \mathrm{C}$ versus that of $\mathrm{Si}-\mathrm{N}$ peak intensities.

the $\mathrm{Si}-\mathrm{O}$ bond absorption, due to post-deposition oxidation, was carefully eliminated from the $\mathrm{Si}-\mathrm{N}$ peak intensity calculation. As shown in Fig. 4, annealing for $16 \mathrm{~min}$ reduced the $\mathrm{Si}-\mathrm{N}$ peak intensities of the $\mathrm{Si}$-rich samples with $\mathrm{N} / \mathrm{Si}$ ratio $<0.72$. Amongst the other samples, the most compact a-SiN $\mathrm{S}_{x}: \mathrm{H}$ with $\mathrm{N} / \mathrm{Si}$ ratio of $\sim 1.3$ have the strongest $\mathrm{Si}-\mathrm{N}$ peak intensity increase. From Fig. 5, an interesting observation is the linear correlation between the variations of the $\mathrm{Si}-\mathrm{N}$ and $\mathrm{Si}-\mathrm{H}$ peak intensities, suggesting a close link between the processes of forming or breaking $\mathrm{Si}-\mathrm{N}$ and $\mathrm{Si}-\mathrm{H}$ bonds.

\section{Discussion}

As can be seen above, both $\mathrm{Si}-\mathrm{H}$ and $\mathrm{N}-\mathrm{H}$ bonds in Sirich material with $\mathrm{N} / \mathrm{Si}<1.02$ lose hydrogen during annealing. Reactions including $\mathrm{Si}-\mathrm{H}$ and $\mathrm{N}-\mathrm{H}$ bond breaking and $\mathrm{H}_{2}$ formation,

$\mathrm{Si}-\mathrm{H}+\mathrm{Si}-\mathrm{H} \rightarrow \mathrm{Si}-\mathrm{Si}+\mathrm{H}_{2} \uparrow$

$\mathrm{Si}-\mathrm{H}+\mathrm{N}-\mathrm{H} \rightarrow \mathrm{Si}-\mathrm{N}+\mathrm{H}_{2} \uparrow$

were previously proposed for this observation [8-10]. In the most Si-rich sample, the decreased $\mathrm{Si}-\mathrm{N}$ peak intensities can be ascribed to reactions forming $\mathrm{NH}_{3}$ fragments [8].

In order to explain the $\mathrm{Si}-\mathrm{H}$ increase after annealing in a-SiN ${ }_{x}: \mathrm{H}$ with $\mathrm{N} / \mathrm{Si}>1.1$, reaction

$\mathrm{Si}-\mathrm{Si}+\mathrm{N}-\mathrm{H} \rightarrow \mathrm{Si}-\mathrm{N}+\mathrm{Si}-\mathrm{H}$

was suggested $[8,10,17]$. This so-called $\mathrm{H}$ migration process, however, was not supported by Savall et al. [9]. They suggested that the enhanced oscillation strength of $\mathrm{Si}-\mathrm{H}$ bonds after annealing can be attributed to a change in the $\mathrm{Si}-\mathrm{H}$ bond absorption. Although such large changes in oscillator strength are possible [18], the observations in Fig. 1(c), i.e. the diminishment of the initial $\mathrm{Si}-\mathrm{H}$ peak and the appearance of a new peak, do not agree with Savall's suggestion. In addition, the linear correlation between the variations of $\mathrm{Si}-\mathrm{H}$ and $\mathrm{Si}-\mathrm{N}$ peak intensities (Fig. 5) supports the possibility of reaction (3). 
The mass density determined by RBS shows that the a$\mathrm{SiN}_{x}: \mathrm{H}$ with $\mathrm{N} / \mathrm{Si}$ close to 1.3 are the most compact. The results in Fig. 2 imply that the $\mathrm{H}$ out-diffusion rate is not directly correlated to the compactness of the films, since no correlation between the two is found.

Bustarret et al. [19] suggested that the $\mathrm{Si}-\mathrm{H}$ peak position is an indication for the different back bonding structures of the $\mathrm{Si}-\mathrm{H}$ bonds. The narrowing $\mathrm{Si}-\mathrm{H}$ peak and the converging peak position to $\sim 2180 \mathrm{~cm}^{-1}$ suggest that $\mathrm{Si}-\mathrm{H}$ bonds with one $\mathrm{Si}$ and two $\mathrm{N}$ back bonding atoms are thermally most stable. However, more work should be done to clarify this topic.

\section{Conclusion}

A thermal annealing experiment has been conducted on a series of a-SiN $: \mathrm{H}$ samples with different $\mathrm{N} / \mathrm{Si}$ atom ratios deposited by HWCVD. Three different types of evolution behaviors were observed for the $\mathrm{a}-\mathrm{SiN}_{x}: \mathrm{H}$ samples, depending on their $\mathrm{N} / \mathrm{Si}$ atom ratios. Bonded $\mathrm{H}$ atoms in more N-rich samples are usually more stable upon thermal annealing.

\section{Acknowledgment}

The research described in this paper was financially supported by the Netherlands Agency for Energy and the Environment (SenterNovem).

\section{References}

[1] A.G. Aberle, Sol. Energy Mater Sol. Cells 65 (2001) 239.
[2] W. Soppe, H. Rieffe, A.W. Weeber, Prog. Photovolt.: Res. Appl. 13 (2005) 551

[3] I.G. Romijn, W.J. Soppe, H.C. Rieffe, A.R. Burgers, A.W. Weeber, in: Proceedings of the 20th European Photovoltaic Solar Energy Conference and Exhibition, Barcelona, Spain, 6-10 June, 2005, p. 1352.

[4] H.F.W. Dekkers, L. Carnel, G. Beaucarne, Appl. Phys. Lett. 89 (2006) 013508.

[5] H. Mäckel, R. Lüdemann, J. Appl. Phys. 92 (2002) 2602.

[6] J. Hong, W.M.M. Kessels, W. Soppe, A. Weeber, W.M. Arnoldbik, M.C.M. van der Sanden, J. Vac. Sci. Technol. B 21 (2003) 2123.

[7] V. Verlaan, C.H.M. van der Werf, Z.S. Houweling, I.G. Romijn, A.W. Weeber, H.F.W. Dekkers, H.D. Goldbach, R.E.I. Schropp, Prog. Photovolt.: Res. Appl. 15 (2007) 563.

[8] Z. Lu, P. Santos-Filho, G. Stevens, M.J. Williams, G. Lucovsky, J. Vac. Sci. Technol. A 13 (1995) 607.

[9] C. Savall, J.C. Bruyere, J.P. Stoquert, Thin Solid Films 260 (1995) 174.

[10] F.L. Martinez, I. Martil, G. Gonzalez-Diaz, B. Selle, I. Sieber, J. Non-Cryst. Solids 227-230 (1998) 523.

[11] R.E.I. Schropp, K.F. Feenstra, E.C. Molenbroek, H. Meiling, J.K. Rath, Philos. Mag. B 76 (1997) 309.

[12] W.M. Arnold Bik, F.H.P.M. Habraken, Rep. Prog. Phys. 56 (1993) 859.

[13] L.C. Feldman, J.W. Mayer, in: Fundamentals of Surface and Thin film analysis, PTR Pentice-Hall Inc., Upper Saddle River, NJ, USA, 1986.

[14] M.H. Brodsky, M. Cardona, J.J. Cuomo, Phys. Rev. B 16 (1977) 3556.

[15] N. Maley, Phys. Rev. B 46 (1992) 2078.

[16] V. Verlaan, Z.S. Houweling, C.H.M. van der Werf, H.D. Goldbach, R.E.I. Schropp, Jpn. J. Appl. Phys. 46 (2007) 1290.

[17] Z. Yin, F.W. Smith, Phys. Rev. B 43 (1991) 4507.

[18] V. Verlaan, C.H.M. van der Werf, W.M. Arnoldbik, H.D. Goldbach, R.E.I. Schropp, Phys. Rev. B 73 (2006) 195333.

[19] E. Bustarret, M. Bensouda, M.C. Habrard, J.C. Bruyere, S. Poulin, S.C. Gujrathi, Phys. Rev. B 38 (1988) 8171. 